\title{
STRUCTURE OF MOGOLTACIN
}

T.Kh.Khasanov, A.I. Saidkhodzhaev,

UDC $547.913 .55: 668.5+587.51$

and G.K. Nikonov

Continuing a study of the coumarins of Ferula mogoltavica collected in the Tadzhik SSR (village of Chashma, Leninabad oblast), by chromatographing a methanolic extract of the roots on a column of silica gel we have isolated a new coumarin $\mathrm{C}_{24} \mathrm{H}_{30} \mathrm{O}_{4}\left(\mathrm{M}^{+} 382\right)$ with $\mathrm{mp} 155-156^{\circ} \mathrm{C}$, $[\alpha]_{\mathrm{D}}^{23}-55^{\circ}$ (c 1.00; chloroform), which we have called mogoltacin (I).

The UV spectrum of (I) has maxima at $218,244,290$, and $326 \mathrm{~nm}(\log \varepsilon 4.25,3.80,4.00,4.24)$, which are characteristic for a 7-hydroxy-substituted coumarin nucleus, and the IR spectrum has absorption bands at 3350-3600 $\mathrm{cm}^{-1}$ (hydroxy group), $1720 \mathrm{~cm}^{-1}$ (carbonyl of an $\alpha$-pyrone), $1660 \mathrm{~cm}^{-1}$ (inflection; double bond), and 1620,1560 , and $1520 \mathrm{~cm}^{-1}$ (aromatic nucleus).

The acid hydrolysis of (I) with a mixture of acetic and sulfuric acids gave umbelliferone, $\mathrm{C}_{9} \mathrm{H}_{6} \mathrm{O}_{3}(\mathrm{II}), \mathrm{mp}$ $231-232^{\circ} \mathrm{C}$, and dehydrogenation with selenium at $220-250^{\circ} \mathrm{C}$ gave $1,2,5,6$-tetramethylnaphthalene $\mathrm{C}_{14} \mathrm{H}_{16}$ (III), with $\mathrm{mp} 113-114^{\circ} \mathrm{C}$.

In this way, it was established that (I) is an ether of umbelliferone and a bicyclic sesquiterpene alcohol with composition $\mathrm{C}_{15} \mathrm{H}_{26} \mathrm{O}_{2}$. The mass spectrum of $(\mathrm{I})$ has the peaks of ions with $\mathrm{m} / \mathrm{e} 382\left(\mathrm{M}^{+}\right), 367\left(\mathrm{M}^{+} \mathrm{CH}_{3}\right)^{+}$, $364\left(\mathrm{M}-\mathrm{H}_{2} \mathrm{O}\right)^{+}, 220(\mathrm{M}-\mathrm{ArOH})^{+}, 203\left(\mathrm{M}-\mathrm{ArO}-\mathrm{H}_{2} \mathrm{O}\right)^{+}, 162(\mathrm{ArOH})^{+}$, which are characteristic for terpenoid coumarins of the iresane group $[1,2]$.

The NMR spectrum of (I) (JNM-4H-100/100 MHz, solutions in $\mathrm{CDCl}_{3}, 0-\mathrm{HMDS}$ ) showed the signals from the protons of tertiary methyl and vinyl methyl groups - singlets at (ppm) $0.80,0.90,0.94$, and $1.68 \mathrm{pp}(3 \mathrm{H}$ each), broadened signals at $3.42\left(\mathrm{~W}_{1 / 2}=6 \mathrm{~Hz}\right)$ and $5.51\left(\mathrm{~W}_{1 / 2}=11 \mathrm{~Hz}\right)$ due to hemihydroxyl and olefinic protons, and a multiplet at $4.11(2 \mathrm{H})$ relating to the methylene proton in an $\mathrm{ArOCH}_{2}$ grouping. In addition, in the $6.22-7.55$ ppm region there were the signals from the five protons of a 7-hydroxy-substituted coumarin.

A comparison of the characteristics of the IR, mass, and NMR spectra of (I) with those of conferol (IV) showed their similarity, but the melting point of (I) was $155-156^{\circ} \mathrm{C}$ and that of (IV) $137-138^{\circ} \mathrm{C}$ 。 $\mathrm{A}$ mixture of (I) and (IV) gave a depression of the melting point, melting at $115-116^{\circ} \mathrm{C}$. To confirm the proposed structure, we performed a transition from mogoltavin (V) [4] to mogoltacin (I). The dehydration of (V) with $10 \%$ sulfuric acid in ethanol for 30 min yielded a substance with the composition $\mathrm{C}_{24} \mathrm{H}_{30} \mathrm{O}_{4}, \mathrm{mp} 155-156^{\circ} \mathrm{C}$, which was identified by its spectra and by a mixed melting point as mogoltacin.

On the basis of the information given, for mogoltacin we propose the most probable structure (I):

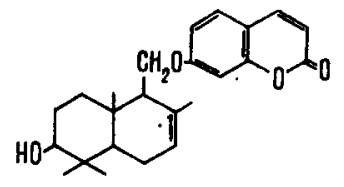

The study of the stereochemistry of (I) is continuing.

\section{LITERATURE CITED}

1. V. Yu. Bagirov, N. P. Kir'yalov, V. I. Sheichenko, and V. V. Bochkarev, Khim. Prirodn. Soedin., 466 (1970).

Institute of the Chemistry of Plant Substances, Academy of Sciences of the Uzbek SSR, Tashkent. Translated from Khimiya Prirodnykh Soedinenii, No. 1, pp. 95-96, January-February, 1976. Original article submitted July 10, 1975.

This material is protected by copyright registered in the name of Plenum Publishing Corporation, 227 West 17 th Street, New York, N.Y. 10011. No part of this publication may be reproduced, stored in a retrieval system, or transmitted, in any form or by any means, electronic, mechanical, photocopying. microfilming, recording or otherwise, without w. 'tten permission of the publisher. A copy of this article is available from the publisher for $\$ 7.50$. 